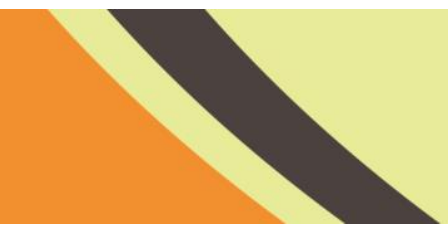

\title{
The Building a Brand and Participation in Decreased Tackling Haze effects and Particulate matter Less Than 2.5 Micron (PM2.5) a Case Study: a Group of Students of Yupparaj Wittayalai School, Chiang Mai Province, Thailand
}

\author{
Suwattanarwong Phanphet ${ }^{1 *}$, Sermkiat Jomjunyong ${ }^{2}$, Ratanaree Suttipong ${ }^{1}$, Saowaluk Reungsri ${ }^{1}$, \\ Athiwat Wangmai ${ }^{1}$ \\ 1Department of Industrial Technology, Faculty of Science and Technology, Chiang Mai Rajabhat University, 202 Chang Phuak Road, Mueang District, \\ Chiang Mai 50300, THAILAND \\ 2Department of Industrial Engineering, Faculty of Engineering, Chiang Mai University, 239 Huay Kaew Road, Mueang District, Chiang Mai 50200, \\ THAILAND \\ *Corresponding author: suwattwong@gmail.com
}

\section{ARTICLE INFO}

Article History:

Received: July 3, 2019

Final Revision: November 14, 2019

Available Online: December 23, 2019

\section{KEYWORDS}

Decreasing the Effects, Climate Change,

PM2.5, STEM Education

\section{CORRESPONDING AUTHOR}

*E-mail: suwattwong@gmail.com

\section{A B S T T R A C T}

\begin{abstract}
The haze problem and particulate matter less than 2.5 microns (PM2.5) in Northern Thailand caused by climate change is directly impacted and indirectly impacted people. In the area is affected by the haze problem and particulate matter (PM2.5) the climate change is health effects of population, As reported by “Air Quality and Pollution City Ranking” on 12 March 2019 The world air-quality index in Chiang Mai province, as the 'Rose of the North' hit top of the scale as the worst polluted city in the world. The air quality index (AQI) hitting a staggering 271 with a diameter of fewer than 2.5 micrometers ranges from 170 micrograms per cubic meter $\left(\mu \mathrm{g} / \mathrm{m}^{3}\right)$ exceeding the safety standard of $50 \mu \mathrm{g} / \mathrm{m}^{3}$ or lower. The pollution is nasty in Chiang Mai, North Thailand, therefore it is necessary to create understanding and awareness of the haze problem and particulate matter in Chiang Mai province. This research is conducted by focusing on Mathayomsuksa 1 students include 40 people who are a group of students of Yupparaj Wittayalai School, Chiang Mai Province, Thailand by exploring the understanding Organize activities to create awareness and participation in reducing the impact of the haze problem and particulate matter through the system "STEM EDUCATION". The results of the activity evaluation made it known that students know the effects of haze problem and particulate matter with an average of 4.46 standard deviations equal to 0.59 . As for the awareness and participation in reducing the impact of the haze problem and particulate matter through the STEM EDUCATION system, the average value is 3.5 , the standard deviation is 0.72 . In the overal picture, the mean is 4.18 . The standard is 0.65 . The level of satisfaction towards training on raising awareness of the haze problem and particulate matter is at a high level. Referring to my previous information, the researcher will develop tools and applications to create awareness and participation in reducing the impact of the haze problem and participate in matter for students in other schools.
\end{abstract}

\section{INTRODUCTION}

The current haze problem and particulate matter less than 2.5 micron (PM2.5) is directly impacted and indirectly impacted for people. In the area is affected by the haze problem and particulate matter (PM2.5). Which is health effects in respiratory diseases caused by climate change that is warmer when it's cold and meets hot air If the wind stays still, the wind does not blow. Another ways caused by smoke from cars, burning the forest, burning garbage, burning farmers and building various things in the city. [1] Due to climate change, this poses health problems for the general population, according to data from the Air Quality and Pollution City ranking data on March 12, 2019 in Chiang Mai Province. It is reported that the global index of air quality is the highest in the world. The air quality index (AQI) is 271, with PM 2.5 of about 170 micrograms per cubic meter [2]. The district in Thailand's Chiang Mai province is likely to face a climate change crisis. Severely Yupparaj Wittayalai School [3] is located in the heart of Chiang Mai. More than 4,000 students in the 2019. The particulate matter and haze crisis have been severely affected. Causing many teachers and students to become ill with respiratory disease and eye inflammation. Make students aware of the problems of climate change Basic health care for oneself 
and loved ones of the affected case. After that, create and design an application allowing students to advertise the reduction of smog and dust problems.

\section{MATERIALS AND METHODS}

STEM is a curriculum based on the idea of educating students in four specific disciplines science, technology, engineering and mathematics in an interdisciplinary and applied approach. Rather than teach the four disciplines as separate and discrete subjects, STEM integrates them into a cohesive learning paradigm based on real-world applications. [5]

STEM learning management is a form of integrated learning. In which the science of the four subjects is combined Make it exceptional in the management of teaching and learning. To help develop thinking process skills Computer skills Problem solving skills and communication skills [6], which are 21st century learning skills, will inspire students to play an important role in the implementation of their learning activities, that they are not just listening. Must learn by experimenting, writing and analysing solutions to everyday problems. This research has designed training methods to create knowledge and understanding. And educate students about smog and dust issues through STEM EDUCATION with the following methods.

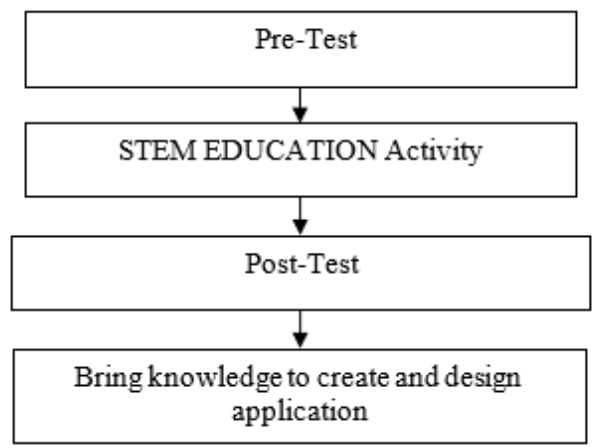

Figure 1. Research Methodology

The Building a Brand and Participation in Decreased Tackling Haze effects and Particulate matter THROUGH STEM EDUCATION. This time, the activity was organized for grade 10 students at Yupparaj Wittayalai School. 40 students in the first half of academic year 2562 in Tables 1 found that students were satisfied with the training provided to educate students about student smog and dust issues. Each element was very satisfying. There is only one element that is at an average level. The students were very satisfied with the results, namely 4.46 , the standard deviation of 0.59 , while the element presenting the degree of satisfaction of the students was at an average level. Does article 1. Relevance of the duration of the training. With an average of 3.5, a standard deviation of 0.72 and an average of 4.18 for a standard deviation of 0.65 , the level of satisfaction with training to raise awareness of smog and dust problems is high.

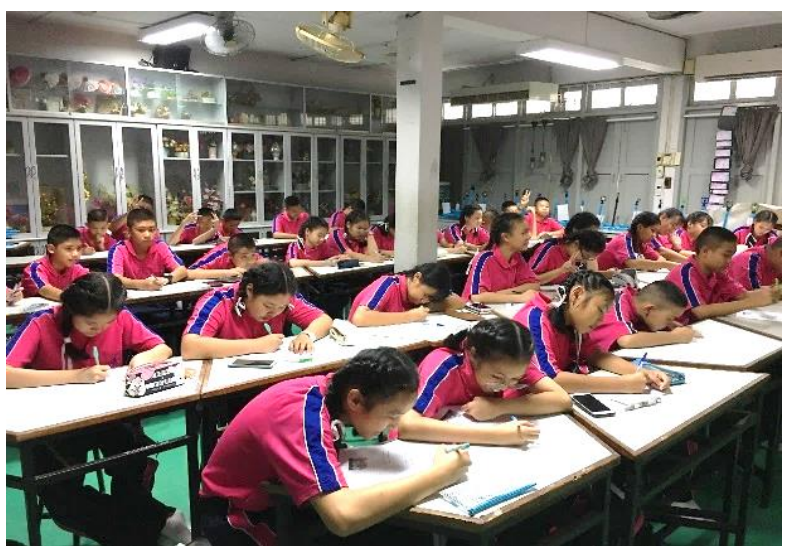

Figure 2. Students who is participate the haze and particulate matter activity

Table 1. Mathayomsuksa 1 student's satisfaction in Data Analysis who training about haze and particulate matter problem Awareness THROUGH STEM EDUCATION

\begin{tabular}{|c|c|c|c|c|c|c|c|c|c|}
\hline \multirow{2}{*}{ No. } & \multirow{2}{*}{ Factors } & \multicolumn{5}{|c|}{ Rating Scale } & \multirow{2}{*}{$\overline{\mathbf{x}}$} & \multirow{2}{*}{ S.D. } & \multirow{2}{*}{$\begin{array}{l}\text { Satisfaction } \\
\text { Score }\end{array}$} \\
\hline & & 5 & 4 & 3 & 2 & 1 & & & \\
\hline 1. & $\begin{array}{l}\text { Suitability } \\
\text { of the } \\
\text { duration of } \\
\text { the training }\end{array}$ & 10 & 20 & 10 & 0 & 0 & 3.5 & 0.72 & Moderate \\
\hline 2. & $\begin{array}{l}\text { Suitability } \\
\text { of place }\end{array}$ & 6 & 15 & 19 & 0 & 0 & 3.65 & 0.73 & Mind \\
\hline 3. & $\begin{array}{l}\text { Suitability } \\
\text { of media }\end{array}$ & 17 & 19 & 4 & 0 & 0 & 4.33 & 0.66 & Mind \\
\hline 4. & $\begin{array}{l}\text { The content } \\
\text { used in the } \\
\text { training is } \\
\text { easy to } \\
\text { understand }\end{array}$ & 18 & 20 & 2 & 0 & 0 & 4.4 & 0.59 & Mind \\
\hline 5. & $\begin{array}{l}\text { The content } \\
\text { of the } \\
\text { training is } \\
\text { interesting }\end{array}$ & 16 & 13 & 11 & 0 & 0 & 4.13 & 0.82 & Mind \\
\hline 6. & $\begin{array}{l}\text { Details of } \\
\text { the content } \\
\text { covered } \\
\text { Complete } \\
\text { and } \\
\text { appropriate }\end{array}$ & 16 & 19 & 4 & 1 & 0 & 4.23 & 0.64 & Mind \\
\hline 7. & $\begin{array}{l}\text { Students } \\
\text { know the } \\
\text { cause of } \\
\text { haze and } \\
\text { dust }\end{array}$ & 18 & 18 & 4 & 0 & 0 & 4.36 & 0.66 & Mind \\
\hline 8. & $\begin{array}{l}\text { Students are } \\
\text { aware of the } \\
\text { effects of } \\
\text { haze and } \\
\text { dust }\end{array}$ & 20 & 18 & 2 & 0 & 0 & 4.46 & 0.59 & Mind \\
\hline 9. & $\begin{array}{l}\text { Students can } \\
\text { apply the } \\
\text { knowledge } \\
\text { gained from } \\
\text { the training } \\
\text { to their daily } \\
\text { lives }\end{array}$ & 16 & 20 & 4 & 0 & 0 & 4.3 & 0.64 & Mind \\
\hline 10. & $\begin{array}{l}\text { Benefits of } \\
\text { training }\end{array}$ & 20 & 18 & 2 & 0 & 0 & 4.45 & 0.59 & Mind \\
\hline \multicolumn{2}{|l|}{ Total } & 157 & 180 & 62 & 1 & 0 & & & \\
\hline \multicolumn{2}{|c|}{ Average } & & & & & & 4.18 & 0.65 & Mind \\
\hline
\end{tabular}




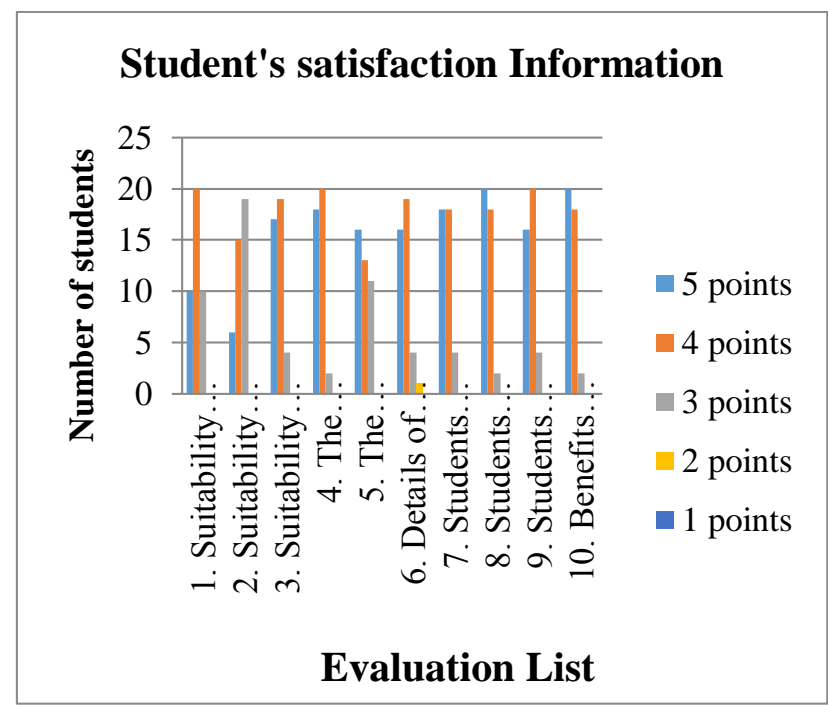

Figure 3. Information on the satisfaction of Mathayomsuksa 1 student's in training on awareness of smog and dust issues. THROUGH STEM EDUCATION

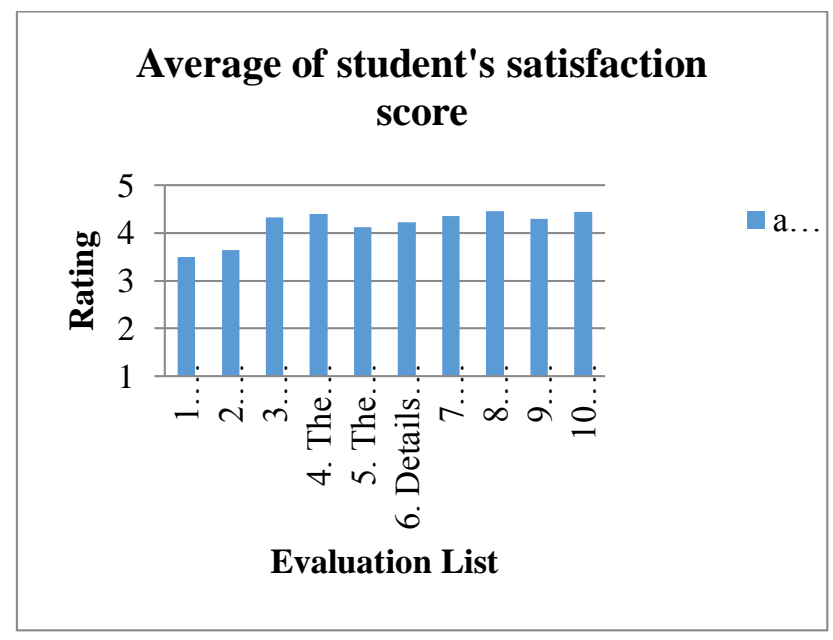

Figure 4. Average satisfaction rating of Mathayomsuksa 1 student's in training to raise awareness of smog and dust problems. THROUGH STEM EDUCATION

\begin{tabular}{|c|c|c|}
\hline Level Score & & \\
\hline Score & $5.00-4.50$ & Very mind \\
\hline Score & $4.49-3.50$ & Mind \\
\hline Score & $3.49-2.50$ & Moderate \\
\hline Score & $2.49-1.50$ & Poor \\
\hline Score & $1.49-1.00$ & Very poor \\
\hline
\end{tabular}

\section{RESULT AND DISCUSSION}

The effect of analyzing mathayomsuksa 1 student's satisfaction data on smog and dust awareness training by Yuparaj Wittayalai STEM EDUCATION In the first half of 2018 academic year, it seems that the students of Mattayomsuksa 1 participate in the activity. A total of 40 people, representing 100\%. And the satisfaction rating of $80 \%$ was very satisfied, the students knew and understood the problems caused by smog and dust. It is through the use of relevant media and video content that is easy to understand and allows students to have a learning process. And students can participate in fun activities Including the ability to apply the knowledge gained From organizing training activities to use at school and in everyday life In conclusion, the project has managed to implement the project, that is to say that after its implementation, it was found that meet all the objectives and goals due to the participation of students and systematic management and development and media interesting and continuous. Implementation of the project giving students a better understanding and awareness of the smog and dust problem of THROUGH STEM EDUCATION. Based on the information above, the researcher will develop tools and applications to increase public awareness and help reduce the impact of smog and dust problems. For students from other schools.

\section{CONCLUSION}

The results showed that students know the effects of haze problem and particulate matter with an average of 4.46 standard deviations equal to 0.59 . As for the awareness and participation in reducing the impact of the haze problem and particulate matter through the STEM EDUCATION system, the average value is 3.5 , the standard deviation is 0.72 . In the overall picture, the mean is 4.18 . The standard is 0.65 . The level of satisfaction towards training on raising awareness of the haze problem and particulate matter is at a high level.

\section{ACKNOWLEDGMENT}

Information support Yupparaj Wittayalai School, Mueang District, Chiang Mai. Financial support Chiang Mai Rajabhat University and Chiang Mai University are gratefully acknowledged.

\section{REFERENCE}

[1]. Pollution Control Department. PM2.5. Ministry of Natural Resources and Environment, Bangkok, Thailand.

[2]. Pollution Control Department. Thailand's air quality and situation reports. 12 March 2019, http://air4thai.pcd.go.th/webV2/index.php

[3]. Yupparaj Wittayalai School, 238 Phrapokklao Road, Mueang District, Chiang Mai 50200, THAILAND

[4]. World Health Organization. (2003). WHO guidelines for air quality. Fact Sheet No. 187. Retrieved from

[5]. Christine V. McDonald. (2016). STEM Education: A review of the contribution of the disciplines of science, technology, engineering and mathematics. Science Education International, 27 (4), 530-569.

[6]. Engineering Design Process to Foster Excitement for STEM in Middle School Students. National Integrated Cyber Education Research Centre. Retrieved January, 22 2018 , 